\title{
BREXIT AND THE FUTURE OF EUROPEAN CRIMINAL LAW - A POLISH PERSPECTIVE
}

\begin{abstract}
Due to a very high number of Polish nationals residing in the United Kingdom (UK), almost half of the European Arrest Warrants ("EAW") issued in Poland over recent years have been executed in the UK. One of the advantages of the EAW is the bypassing of rules preventing the extradition of a state's own nationals. According to Polish law, in the case of extradition under an international agreement, the possibility of extraditing Polish nationals must be included in the agreement. One of many possible repercussions of Brexit - replacement of the EAW with a "traditional" extradition procedure - may result in substantial slowing down of the extradition and making the procedure much more expensive. This risk seems to be confirmed by some recent Polish cases discussed in this brief paper.
\end{abstract}

\section{INTRODUCTION}

The possible influence of Brexit on international cooperation in criminal matters may be discussed on various levels, one of which is the local perspective of individual EU-member states. In this brief paper, we would like to focus on some practical issues concerning mutual cooperation in criminal matters between Poland and the UK. This is of special interest, mainly because the number of Polish nationals residing in the UK is almost one million. ${ }^{1}$ Therefore, it is not surprising that, in terms of police and judicial cooperation, the

\footnotetext{
* Andrzej Światłowski is a Professor at Jagiellonian University (Kraków, Poland), E-mail: andrzej.swiatlowski@uj.edu.pl. Barbara Nita-Światłowska is a Professor at the University of Economics and Judge of the Court of Appeal (Kraków, Poland), E-mail: barbara.nita1@gmail.com.

${ }^{1}$ According to the Office for National Statistics, in 2015 the number of Polish residents in the UK was approximately 916000 , amounting to the biggest national minority in the UK; cf. https://www.ons.gov.uk/peoplepopulationandcommunity/ populationandmigration/internationalmigration/datasets/populationoftheunitedking dombycountryofbirthandnationality, last visited 25 March 2017.
} 
application of the European Arrest Warrants (EAW) between Poland and the UK is of particular importance. In recent years, almost half of the EAWs issued in Poland have been executed in the UK. ${ }^{2}$

At the time of writing, it is not yet possible to predict the final form of Brexit. In order to show the possible direction of travel, we will briefly sketch the legal background of Polish law.

\section{EUROPEAN ARREST WARRANT AND EXTRADITION IN POLISH LAW}

All the acquis communautaire became part of the Polish legal system on 1 May 2004, which was the date of the Polish accession to the EU. Subsequently, the secondary law instruments, especially framework decisions and directives, were gradually implemented. All the implementing regulations of Polish domestic law take precedence over other statutory regulations. Similarly, they take precedence over the statutory regulations that implement the international agreements binding upon Poland. ${ }^{3}$ Part XIII of the Polish Code of Criminal Procedure ("CCP") deals with "criminal procedure in international relations". Initially, it encompassed only 37 sections in 7 chapters; currently, it amounts to approximately 200 sections in 24 chapters. This growth is mostly a result of the implementation of EU law.

As a rule, the provisions of Part XIII CCP are subsidiary in relation to the international agreements. According to Art. 91.2. of the Polish Constitution, "[a]n international agreement ratified upon prior consent granted by the statute shall have precedence over statutes if such an agreement cannot be reconciled with the provisions of such statutes". This general rule is also repeated in Art. $615 \S 1$ CCP. What is then the relationship between the provisions of Part XIII

\footnotetext{
${ }^{2}$ For example, the number of EAWs issued in Poland and resulting in effective surrender in 2016 was 1541 . Among them, 745 were the surrenders from the UK. At the same time, the number of surrenders from Germany was 366, from the Czech Republic 13, and from Italy 18; cf. "ENA - europejski nakaz aresztowania w latach 2004-16", https://isws.ms.gov.pl/pl/baza-statystyczna/opracowania-wieloletnie/, last visited 25 March 2017. Also from the UK's point of view, more than a half of the surrenders pursuant to an EAW go to Poland; cf. https://www.gov.uk/government/ uploads/system/uploads/attachment_data/file/209691/Part_1_by_Country_Offence_ and_Nationality.pdf, last visited 15 March 2017.

${ }^{3}$ Art. 9 of the Polish Constitution and the Judgement of the Constitutional Court of 27 April 2005, P 1/05 OTKZU 4/A/25/42.

${ }^{4}$ Unofficial translation, http://www.sejm.gov.pl/prawo/konst/angielski/kon1.htm, last visited 25 March 2017.
} 
CCP, implementing EU law, on the one hand, and international agreements on the other? Neither Art. $615 \S 2$ CCP nor the Constitution answers this question. However, it seems to be clear that the provisions of Part XIII CCP also take precedence. In other words, the mutual cooperation in criminal matters outside the EU (e.g. with the USA) has to meet the same standards of protection of fundamental rights as within the EU, even if an applicable bilateral (or multilateral) agreement does not require it. ${ }^{5}$ The aforementioned precedence may have vital importance in the case of Brexit. Even if the UK falls outside the present EU system of cooperation, Polish Courts will still be bound by this system.

Poland is a party to the European Convention on Extradition ("EuCExt") of 13 December 1957 and its protocols. ${ }^{6}$ Some provisions on extradition are to be found also in the European Convention on the Suppression of Terrorism of 27 January $1977 .^{7}$ According to its Art. 3, the provisions of all extradition treaties and arrangements applicable between Contracting States, including the EuCExt, are modified between Contracting States to the extent that they are incompatible with this Convention.

An obvious advantage of the EAW is the bypassing of rules preventing the extradition of a state's own nationals. ${ }^{8}$ Poland does not extradite $^{9}$ its nationals unless pursuant to an EAW or other specific conditions (in case of international core crimes, covered by the jurisdiction of the International Criminal Court and other international courts, cf. Art. 55.1-3. of the Constitution).

Both "traditional" extradition and the EAW are applicable to Polish citizens only if possible under an international agreement binding upon Poland or a statute implementing the law enacted by an international organisation of which Poland is a member. The possi-

${ }^{5} \mathrm{P}$ Hofmański, E Sadzik and $\mathrm{K}$ Zgryzek, Kodeks postępowania karnego. Komentarz, Vol III (Warszawa, C.H. Beck, 2012) 1085; also P Hofmański and A Sakowicz, 'Reguły kolizyjne w obszarze międzynarodowej współpracy w sprawach karnych' (2006) 61 Państwo i Prawo 11/29.

${ }^{6}$ Thereto K Ambos, European Criminal Law (Cambridge, CUP, 2017) Ch. IV mn. $21 \mathrm{ff}$.

${ }^{7}$ ETS No. 90.

${ }^{8}$ See thereto and generally on the EAW Ambos, European Criminal Law, above $\mathrm{n}$ 6 at Ch. IV mn. 14, $43 \mathrm{ff}$.

${ }^{9}$ The guarantees provided by the Art. 55 of the Constitution of the Republic of Poland of 1997 cover both the classical extradition and the EAW. See the Judgements of the Constitutional Court: P 1/05 of 27 April 2005 r., and SK 26/08 of 5 October 2010. 
bility of an extradition of Polish nationals must be included in the respective agreement. ${ }^{10}$ This is, of course, not necessary in the EAW framework where the surrender of nationals is always possible. Otherwise, the extradition of Polish nationals is prohibited. ${ }^{11}$

\section{TWO RECENT CASES AS EXAMPLES}

Of course, a substantial slowing down of the procedures may be expected if the EAW is replaced with traditional instruments. In order to illustrate this risk, let us refer here to two recent cases of the Court of Appeal in Kraków. ${ }^{12}$

In its decision of 30 May 2016, the Kraków Court of Appeal upheld the decision of the Provincial Court, refusing the early conditional release of Polish national $\mathrm{Mr} \mathrm{F}{ }^{13} \mathrm{He}$ was sentenced to 7 years' imprisonment and later fled to Australia. Awaiting the decision of the Australian authorities, Mr F. has already been detained in Australia for more than 5 years (!) for extradition back to Poland. His motion for early release was rejected because he had not served the required minimum of half of the sentence. ${ }^{14}$ At that time, there were no grounds to credit the time spent in custody in Australia towards the penalty.

Another example is the decision of the Court of Appeal in Krakow of 29 December $2016 .{ }^{15}$ A Polish national, Mr W., was charged with $1^{\text {st }}$ Degree Homicide in Chicago, Illinois, and faces the maximum penalty of 60 years' imprisonment. In accordance with the jurispru-

\footnotetext{
${ }^{10}$ It is worth mentioning, that according to the declaration contained in the instrument of ratification, deposited on 15 June 1993, the Republic of Poland declared, in accordance with Art. 6 (1) (a) of the European Convention on Extradition, that it will under no circumstances extradite its own nationals. On the other hand, according to Art. 4.1. of the Extradition Treaty Between the United States of America and the Republic of Poland "[n]either Contracting State shall be bound to extradite its own nationals, but the Executive Authority of the Requested State shall have the power to extradite such persons if, in its discretion, it be deemed proper and possible to do so."

${ }^{11}$ Art. $604 \S 1$ pkt 1 CCP.

${ }^{12}$ Sad Apelacyjny, one of 11 courts of this level in Poland, comparable to Oberlandesgericht in Germany.

${ }^{13}$ Case number: II AKzw 71/16.

${ }^{14}$ Art. 78 \& 1 Criminal Code.

${ }^{15}$ Case number: II AKz 162/16.
} 
dence of the European Court of Human Rights, ${ }^{16}$ binding upon Poland in this case, the Court considered this sentence as amounting to life imprisonment. Thus, extradition from Poland to the USA could be admitted only if the law of Illinois guarantees access to early release in the case of a sentence exceeding 25 years or, if not, the convicted defendant may be returned to Poland to serve his sentence in a Polish prison. The Court of Appeal requested necessary information on the law and practice of Illinois on 24 May 2016. According to Art. $613 \mathrm{CCP}$, the request was not sent directly, but through the Ministry of Justice. Immediately after the answer arrived (also via the Minister of Justice), another request was sent on 28 September. This time the Court of Appeal asked whether the US authorities would guarantee the return of $\mathrm{Mr} \mathrm{W}$. to Poland to serve the sentence if he were sentenced for more than 25 years. ${ }^{17}$ The respective guarantee was given on 30 November 2016.

This example shows the difference between the direct exchange of information typical for EU cooperation and the "traditional" timeconsuming inter-governmental method. It is worthwhile pointing out in this context that in the case of provisional detention, the delay in exchange of letters in the course of an extradition procedure is not a ground for extension of the detention. Moreover, unreasonably long detention may result in an application for compensation if the extradition fails. In such cases, the civil liability of the state does not require fault on the part of the public agent. This problem is not merely theoretical. In January 2017, the Provincial Court ${ }^{18}$ in Warsaw ordered 327,000 PLN compensation to Mr A.A.M., a British national, for detention in Poland related to his extradition to the USA. Before the extradition was found inadmissible, he spent two years in custody because obtaining the testimony from a crucial witness in the USA took 2 years. ${ }^{19}$

\footnotetext{
${ }^{16}$ See Art. 3 of the ECHR and the cases ECtHR, Vinter and others $v$. UK, Application nos. 66069/09, 130/10 and 3896/10, Judgment (9 July 2013) and Trabelsi v. Belgium, Application no. 140/10, Judgment (4 September 2014); thereto Ambos, European Criminal Law, above $\mathrm{n} 6$ at Ch. II mn. 119.

${ }^{17}$ See Čalovskis v. Latvia, Application nr. 22205/13 of 24 July 2014.

18 Sąd Okręgowy.

19 'Sąd: 327 tys. zł dla Irańczyka za niesłuszny dwuletni areszt w Polsce', Rzeczpospolita, 01.02.2017, http://www.rp.pl/Cudzoziemcy/302019921-Sad-327-tys-zl-dlaIranczyka-za-niesluszny-dwuletni-areszt-w-Polsce.html, last visited 25 March 2017.
} 


\section{CONCLUSION}

According to the EAW Framework Decision and Art. $607 \mathrm{k} \S 3$ CCP, detention during execution of the EAW must not exceed 100 days. In turn, according to Art. $607 \mathrm{~m} \S 1$ and $\S 1$ a CCP, the decision of the court must be taken within 40 days of the day of the arrest and the final decision should be taken within 60 days. In practice, this works quite well.

In sum, it is clear that the aforementioned adverse consequences would not arise within the EAW framework. Giving evidence to the House of Lords EU Home Affairs Sub-Committee, Professor Steve Peers discussed the possibility of reverting to the pre-existing Convention: "We can go back to a Council of Europe system, of course. (...) $[\mathrm{B}]$ ut be aware that it will mean not only transitional challenges, which we are getting already, but significantly fewer people extradited, taking significantly longer and quite possibly more expensive in each case." ${ }^{20}$ We think that we should be aware of these risks and that these words are fully confirmed by the Polish experience.

\section{OPEN ACCESS}

This article is distributed under the terms of the Creative Commons Attribution 4.0 International License (http://creativecommons.org/ licenses/by/4.0/), which permits unrestricted use, distribution, and reproduction in any medium, provided you give appropriate credit to the original author(s) and the source, provide a link to the Creative Commons license, and indicate if changes were made.

20 "Brexit: Future UK-EU Security and Police Cooperation, House of Lords European Union Committee, Evidence session 1", 14 September 2016. 